\title{
A Question of Identity
}





\section{A Question of Identity}

Social, Political, and Historical Aspects of Identity Dynamics in Jewish and Other Contexts

Edited by

Dikla Rivlin Katz, Noah Hacham, Geoffrey Herman, and Lilach Sagiv

\section{DE GRUYTER \\ OLDENBOURG}


Published with the kind support of the Mandel Scholion Interdisciplinary Research Center in the Humanities and Jewish Studies at the Hebrew University of Jerusalem.
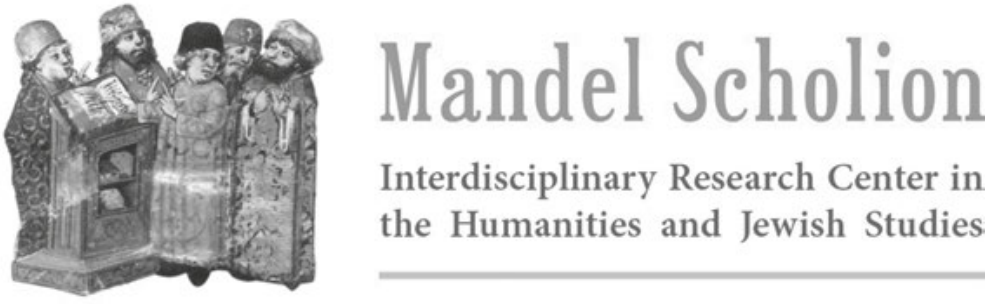

\section{Interdisciplinary Research Center in} the Humanities and Jewish Studies

ISBN 978-3-11-061248-6

e-ISBN (PDF) 978-3-11-061544-9

e-ISBN (EPUB) 978-3-11-061281-3

Library of Congress Control Number: 2018967115

Bibliographic information published by the Deutsche Nationalbibliothek

The Deutsche Nationalbibliothek lists this publication in the Deutsche Nationalbibliografie; detailed bibliographic data are available on the Internet at http://dnb.dnb.de.

(C)2019 Walter de Gruyter GmbH, Berlin/Boston

Typesetting: Integra Software Services Pvt. Ltd.

Printing and binding: CPI books $\mathrm{GmbH}$, Leck

Cover Illustration: Photographer: G. Laron, by courtesy of: Prof. Zeev Weiss, Zippori Excavation, The Hebrew University of Jerusalem.

www.degruyter.com 